\title{
ON BEING CONSERVATIVE
}

\author{
BY JOHN W. OSBORNE
}

I

$\mathrm{N}$ his preface to Lyrical Ballads, William Wordsworth noted that, "All men feel something of an honourable bigotry for the objects which have long continued to please them." This statement reflects a fundamental truth about conservatism: its belief in continuity. As a philosophy, conservatism is distrustful of aimless experiment and frivolous innovation. In practical matters no conservative would pull up a plant by its roots in order to see how it was growing.

Wordsworth's recognition of human feeling for familiar objects indicates in a small way a wider truth. For a conservative believes in an endless chain of human experience; hence, the value of studying history. Since human nature does not change, the lessons of the past are alive and relevant today. Specifics alter, details vary but in all respects human beings face the same fundamental problems that their ancestors have encountered throughout the ages. In no important characteristic-intellectual capacity, emotional stability, moral strength-are we different from those pioneers who beheld the dawn of civilization some seven thousand years ago. But we do have one advantage: it is civilization itself and modern man can see the human record in all its good and evil across the centuries and (hopefully) profit from it.

Hence the importance of continuity. Our society is, as Edmund Burke said, organic, and we are linked to the past and to the future through the shared experience of the human race. The real growth which we call progress is slow and gradual. Since society is organic and not a machine, it cannot be altered promiscuously. Change must be in conformity to the nature of the existing social framework; it must consider all factors and work with the grain of experience rather than against it. Everything about human society is so subtle that the conservative will reject as over simple panaceas designed to solve its problems. Society must grow into change.

Conservatism is not an ideology; it is a way of life. While favoring a free-market economy, it does not believe in the economic theory of history, considers Marxism to be impertinent and eschews reductionism in psychology. The conservative believes man to be much too complex to be considered on the basis of a single cause or 
explanation. Furthermore, with his unified though hierarchical view of society the conservative hates the thought of class war. Similarly, conservatism is the antithesis of fascism with its cult of the leader, mass meetings, aggressive militarism and truculent nationalism. Conservatism is a gentle thing.

Fascism and communism being totalitarian are as far from conservatism as it is possible to get. The conservative loves diversity, liberty, individualism and tradition; he is for variety and against conformity. Further, the conservative is generally tranquil and even happy in his approach to life and cannot appreciate the solemnity and sullenness of the totalitarian radical. Like Burke, he makes a plea for the "little platoons." He sees human society as a whole but also in terms of the needs of its individual members. In essence, the conservative believes with Dr. Johnson that happiness does not at bottom depend upon forms of government. And that is why so many conservatives are bored with politics, preferring instead to enjoy life in all of its abundance and variety.

Nevertheless, the conservative does have certain political principles which he will defend to the death. Above all, he values liberty and believes that liberty and equality are not synonymous but may even be opposites. He sympathizes with Randolph of Roanoke who said that, "I am an aristocrat. I love liberty, I hate equality." To the conservative there is a natural aristocracy among men. This aristocracy is not of birth or wealth, though natural aristocrats may be found among people with titles and those who possess great riches. But it is more typically found in all income groups and even among the uneducated. The natural aristocrat is apparent in his words, thoughts and deeds. He conforms in many respects to John Henry Newman's definition of a gentleman as having "a delicate taste, a candid, equitable, dispassionate mind, a noble and courteous bearing in the conduct of life. . . ." Men like these are created to be the leaders of society, the group to which all others should properly defer.

But how can this be reconciled with a belief in natural and inalienable rights and in the pursuit of happiness? To begin with, the conservative does not believe in natural rights; he believes in prescriptive rights which grow by increments through age. Natural rights have a tendency to be very imprecise and often cause great mischief when attempts are made (as in the French Revolution) to define them and to put them into practice. Prescriptive rights are 
more definite. They include the right to live under a rule of law, the right to own property and the right to inherit wealth. These are specific rights and although the conservative in his private life and attitude toward culture may be romantic, in law and politics he prefers the concrete to the abstract.

In the same vein, pursuing happiness as an individual may cause unhappiness to others since people can find happiness in strange ways. Besides, the conservative extends his hierarchy of belief to happiness as well as social structure and as we shall see abhors the utilitarian idea of all forms of pleasure as being equal. The conservative conserves the traditional order of things and traditional values; he could never believe in the unalloyed goodness of man or in vox populi, vox dei.

People are more in need of restraint than they are of liberty and duties must accompany rights. As Goethe said, "Everything that liberates the spirit without a corresponding growth in self-mastery is pernicious." There is no inconsistency here. While it is true that modern conservatives are generally suspicious of large government they are not anarchists since they recognize that some government is necessary to restrain human passions and to provide order in society.

The conservative takes seriously the idea of rule of law. But law must conform to the needs and instincts of the people and not be used as coercion for social changes. Especially must law avoid being the tool of theoreticians who aim at vast social engineering projects which cannot work since they do not conform to what philosophy and history tell us is true of the human personality. In this matter it is not that the conservative fails to respect human reason. He does, but he also values emotion, feeling, instinct and even prejudice because he is concerned with the whole human being.

The conservative could interpret Burke's "unbought grace of life" to mean such things as personal affection and what the late Harold Nicolson meant when he said that, "I have loved learning, scholarship, intelligence and the humanities." Nicolson's pleasures included a famous garden, men's clubs, friends, "foreign travel, the purchase of books and pictures, and the unthinking enjoyment of food and wine." This is the view of a highly civilized conservative and is caviar to the general. How about the average man or woman of conservative views? Educated conservatives will deny that the love of fox hunting, needlework, sports cars or the New York Jets football 
team is in the same class as Nicolson's enumerated pleasures. Remember, the conservative is not an equalitarian. But all conservatives will agree that these pastimes are preferable to an absorption in social causes and a discontent with a way of life that most people find tolerable.

All conservatives also enjoy the emotion of loyalty to the nation state while recognizing that unbridled nationalism has been the curse of the twentieth century. Conservatives try to steer a middle course of honest patriotism which acknowledges blemishes as well as glories in one's own country and avoids the extremes of chauvinism and disloyalty. He regards his country as an aged parent to whom veneration and love are due despite any flaws which might exist and, in instructing the young, will emphasize the best features of the nation rather than its weaknesses.

In the past most conservatives have had a belief in the religious basis of society. Now, however, we have an example of conservatism evolving so that it is possible for its followers to accept the findings of modern biological and physical science, to deny religion, and yet still be conservative. Nevertheless, while many modern conservatives may be agnostic, they value religion as a social cement and recognize that it restrains human passions and imposes a healthy order upon the chaos of emotion.

Not that the conservative is always opposed to emotion. We have already said that he is not. He can feel tender passion and may consider that the private matter of being in love is the most important thing in the world. As Pascal said, "The heart has its reasons that the mind knows not of."

Above all, the conservative conserves. As Kenneth Clark has said, "I believe that order is better than chaos, creation better than destruction. I prefer gentleness to violence, forgiveness to vendetta. On the whole I think that knowledge is preferable to ignorance, and I am sure that human sympathy is more valuable than ideology. I believe that in spite of the recent triumphs in science, men haven't changed much in the last two thousand years; and in consequence we must still try to learn from history." The conservative takes pride in civilization and sees it as a conservative force. True to the historic tradition of conservatism, the conservative is cosmopolitan in matters of culture, recognizing merit and achievement regardless of its source. In no way does this conflict with his patriotism.

Conservatism thus aims at developing a complete human being 
who ideally is a harmony of reason and sentiment. The conservative seeks wisdom rather than knowledge. Realizing the complex nature of the human personality and recognizing weaknesses as well as strengths, the conservative is suspicious of plans, whether elaborate or simple, for dealing with the problems of society. When he has to treat with social issues, freedom is his goal, moderation his method and respect for continuity and tradition his guide. 